\title{
THE CURRENT STATE OF UKRAINE'S LEGISLATION AND THE PROBLEMS OF ITS INTERVENTION
}

\section{Samsin I. L.}

\section{INTRODUCTION}

In the scientific community, a debate has been held to date on whether the provisions of legislation are always needed to be interpreted. At this time, the teaching literature included the idea that the application of the provisions of the legislation is necessarily preceded by their interpretation. With such an opinion, one should agree with the review as to the legislation, its nature, content, the correlation with the law, especially its current state in Ukraine, as well as the content of legal interpretation.

Therefore, law enforcement authorities, and especially judges, should not continue to avoid indicating in court decisions on the interpretation of acts of law that they carry out in deciding cases. Until the adoption of the new Law of Ukraine "On the Constitutional Court of Ukraine", the idea was that the interpretation was the prerogative of the Constitutional Court. Today, the Constitutional Court has a constitutional mandate to carry out a normative (mandatory for an indefinite number of persons) interpretation of the Constitution of Ukraine only. Therefore, the individual interpretation of legislative acts (in relation to legal relationships that have arisen between specific individuals) is the authority that all the courts have to give and which they must exercise on a daily basis in order to motivate the decisions they make. In the judicial decision, it is necessary to interpret the provisions of the law applicable to the specific legal relationships, to clarify in what way the relevant rights and obligations of the parties follow from the relevant provisions of the law. Without this, the judicial decision will be incomprehensible to the participants in the process, and consequently their right to a fair trial will be violated.

Legislation is a set of certain binding rules for the implementation of provisions incorporated into regulations. And, at first glance, a judge or other person who should apply the law or give legal qualification to actions of persons or other circumstances, or to find out the content of the rights and obligations of the participants in the relevant legal relationships, should only find the law of the law, carefully read and apply to the relevant legal relationship.

In fact, in practice, the interpretation is much more complex. This is primarily due to the fact that, for the correct application of law, it is necessary from the 
text of the act of legislation as a real phenomenon that is perceived by a person through her feelings and mind, to turn to the system of law that exists only as a phenomenon of logic, and by means of such a transition, to outline a circle of legal norms, which are subject to the applicable legal relationship. In addition, the system of legislation is multilevel, branched out. Therefore, implementation of enforcement implies taking into account the place of the provisions of the legislation to be applied, in the system of legislation, taking into account the systemic links between the provisions of legislative acts. There are even grounds for the assertion that the court's decision in a particular case is to apply to the relevant legal relationship not a specific provision of a separate act of the law, but legislation in the whole.

Interpretation of legislative acts is a complex legal activity, the success of which depends on the correct application of the provisions of the law and the fair resolution of disputes.

\section{The need for interpretation of legislative acts, its significance and development trends}

According to V. Vitushko, interpretation is a necessary element of the law enforcement process, which consists of establishing and clarifying the rule of law ${ }^{1}$.

At one time, the scientist-proceduralist Y.V. Vaskovskii successfully noticed that in legislation, no matter how perfect it was, there are gaps, ambiguities and contradictions. This leads to contradictions in the ways of understanding and applying its norms; in each constituency one can practice its own practice, and the same things will be solved in different districts in different ways. The lack of uniformity in judicial practice destroys the unity of state law and order, weakens the force of law and undermines the principle of equality of all citizens before the law ${ }^{2}$.

The literature rightly notes the practical orientation of the theory of law enforcement, which is determined by its directly applied character ${ }^{3}$. The actual theory of law enforcement is now an integral element of legal science and has a paradigm, a basic character ${ }^{4}$.

Professor E.V. Dodin in particular, he notes that the purpose of law enforcement activities is to extend the general provisions of legal norms to personally defined entities, and its content is the collection, research, processing

\footnotetext{
1 Vitushko V. New technologies for the interpretation of law. Justice of Belarus. 2001. № 1. URL: http://www.justbel.info/ search.htm

${ }^{2}$ Vaskovsky E.V. Tutorial of the Civil Process / ed. V.A. Tomsinov. Moscow : Publishing house "Zertsalo", 2003. P. 35.

${ }^{3}$ Rabinovich P.M. Fundamentals of the general theory of law and state: teach. Manual. View. 5th from changes. Kiev, 2001. P. 132.

${ }^{4}$ Kuhn T. The Structure of Scientific Revolutions. Moscow, 2002. P. 34-35.
} 
and storage of information ${ }^{5}$. According to S.S. Alekseyev, law enforcement activity is an organizational expression of the application of law and represents a system of dissimilar actions of the main and auxiliary character, embodied in the legal acts. At the same time, he recognizes law enforcement as a specific activity aimed at resolving a legal case ${ }^{6}$. The law-enforcement activity is sometimes defined as carried out on the principles of expediency, fairness and reasonableness, the subordinate activity of competent entities for the publication of specific and individual power regulations (individual regulation) and the provision of their publication and actual implementation (right of provision) ${ }^{7}$.

O. Kozlov expresses a rather interesting position on the application of law enforcement, which notes that the competent entity must consistently acquire knowledge about a particular situation that needs to be resolved, the content of the norm to be implemented, possible favorable or negative for the legal consequences of the subject and approve the corresponding a decision verifying the nature and extent of the rights and obligations of the participants in the legal relationship and, if necessary, determining the nature and extent of legal liability ${ }^{8}$.

D. Bocharov notes that the concept of "law-enforcement activity" has the basic features: first, it is a specific activity of competent subjects. Unlike such forms of direct implementation of legal norms, such as their use, enforcement and compliance by citizens, etc., enforcement is a complex form of implementation of the rules of law requiring the participation of the subject of the legal authority of the subject, and secondly, such activities are marked by a power of attorney; thirdly, it is an activity on individual regulation and law enforcement, that is, providing for the publication of specific and individualized power regulations that define the subjective rights and obligations of the addressees of the orders, and ensuring their actual realization by the addressees in the form of execution and compliance with the subctive duties and prohibitions, as well as the use of subjective rights; fourthly, this activity should be carried out on the principles of expediency, justice and justification, since it is carried out with the aim of the most effective regulation of social relations and under the condition of transparency of the grounds for the approved decisions ${ }^{9}$.

\footnotetext{
5 Dodin E.V. Evidence and Evidence in the Law Enforcement of the Soviet Government Bodies. Kiev; Odessa, 1976. 128 p.

${ }^{6}$ Alekseev S.S. Ascension to Law: Searches and Solutions. Moscow, 2001. P. 320-323.

Bocharov D.O. Law-enforcement activities: concepts, functions and forms: Problem lectures. Dnipropetrovsk : AMSU, 2006. 73 p.

${ }^{8}$ Kozlov A.S. On the Conceptuality of the Theory of Evidence in the Jurisdiction. Actual problems of the theory of legal evidence: sat. scientific book. Irkutsk, 1984. P. 4.

9 Bocharov D.O. Law-enforcement activities: concepts, functions and forms: Problem lectures. Dnipropetrovsk : AMSU, 2006. 73 p.
} 
Thus, the interpretation of legislative acts is a prerequisite for law enforcement as a result of the implementation of the rules of law. Interpretation in this sense can be considered as a separate stage or element of enforcement, it is an inherent part of this process, without which the latter will not have sufficient legal justification.

In order to build Ukraine as a rule of law, in which the rule of law will be ensured, the problem of the interpretation of legislative acts becomes important. This is primarily due to the lack of experience that, in the field of law enforcement, was our society on the eve of the perception of the idea of a rule of law and the rule of law. To date, the idea of a rule of law and the rule of law is perceived by Ukrainian society in the same way as the idea of communism: we will not succeed in any of these, but if we need to simulate the development of a state governed by the rule of law, we will pretend to do so. Ten years after the adoption of the Constitution, S.V. Shevchuk, the Chairman of the Constitutional Court of Ukraine, stated in relation to Ukraine that "the basic human rights fixed in the Convention (on the protection of human rights and fundamental freedoms - Auth.) and the Constitution of Ukraine, for the most part, remain purely declarative and used as slogans for another political campaign". Absolutely nothing changed after twenty years.

The analogy of the development of the rule of law in Ukraine and the establishment of the rule of law principle with the construction of communism in the Soviet Union particularly expresses the essence of things in the context of the statement of the famous Russian writer F. Dostoyevsky that the idea of socialism is not invented to raise the earth to heaven, but to bring down the heavens to the earth. Indeed, the process of raising society to the idea of a rule of law and the rule of law (to heaven) and the establishment of the rule of law principle does not go or go too slowly. And the main thing is that in Ukraine there are many different public organizations that are aimed at implementing the rule of law principle, but, unfortunately, today it is not seen to be used in the practical work of courts. Moreover, with similar faces and on their way of professional activity. This suggests that law enforcement agencies and courts do not have professional experience and do not properly perceive the legal nature of fundamental rights and freedoms and do not dare to adequately apply them in their practice. This indicates that the courts and judges did not receive independence and were subordinated to the ruling elite.

It should also be taken into consideration that the understanding of the need to develop and study the methodology for the interpretation of legislative acts is gradually ripening among academics. In particular, well-known comparative law researchers R. David and K. Geoffre-Spinoza write: "The meaning of lawyer training is not that he has learned [...] the norms that are current today [...] For 
the lawyer there is an important understanding of the structural relationship of norms, terms, the ways in which these rules operate, the ways in which they are used to fix norms and their agreement among themselves" ${ }^{\text {" }}$.

Courts and law enforcement agencies apply the law that is there. And they are not authorized to give a general assessment of legislation or to make individual decisions about the ambiguity of a legal act or the existence of contradictions between legislative acts. But a general scientifically based assessment of legislation is needed. That significant amount of research work done by scientists in interpreting legislative acts provides grounds for the following statements. During the years of Ukraine's independence, domestic legislation has radically renewed. Yet the indisputable fact is that due to the intensive lawmaking activity, the legislation since the day of Ukraine's independence was developed through its inadequate elaboration, unjustified complication, a significant reduction in the level of formal certainty and a sharp increase in the contradiction between normative and legal acts. This also applies to the Constitution of Ukraine, and the codified legislative acts, and other laws, and even more so subordinate normative legal acts. It is clear that the interpretation of such legislation is much harder than the formally defined, free of contradictions, well-worked out and simply and clearly stated. In modern Ukraine, the legal system is characterized by intense rule-making activity. Therefore, a number of problems of the legislative process arise concerning the low-quality legislation, the continuous violation of the Rules of the Verkhovna Rada of Ukraine and the low level of interaction of subjects of legislative initiative in the legislative process. Although, the main legal department of the Verkhovna Rada of Ukraine has prepared methodological recommendations on the Rules for drafting laws and the main requirements of legislative technique, but, unfortunately, they do not give a positive result in the adoption of laws.

According to the OPORA Civic Network, as of December, 2017, for 3 years of the parliament's work, only $11.08 \%$ of the submitted bills to the Verkhovna Rada of Ukraine became the laws ${ }^{11}$. Therefore, in order to improve the quality of laws, it is necessary to establish certain standards for normative design for all subjects of legislative initiative. There should be the same requirements for unification and specification of requirements for normative drafting and submission of bills. In Ukraine, for many years, work is underway to develop and adopt a law "On Laws and Legislation". The first attempt to adopt such a legal act was in 2001, however, not successful, because the president vetoed this law. Later, a number of drafts of the Law of Ukraine "On Regulatory Acts" were

\footnotetext{
${ }^{10}$ David R., Joffre-Spinoza K. Basic legal systems of the present. Moscow : International relations, 1998. P. 19.

${ }^{11}$ Ways to improve the quality of the legislative process. Does the law "On Laws and Legislative Activity Needed?". Program advice: responsibility, accountability, democratic parliamentary representation. URL: http://zakon2.rada.gov.ua/laws/show/1392-2011-ח.
} 
developed (1343-1 of 21.01.2008, 5199-VI of 06.09.2012), after which the consideration of the matter was stopped. For today and for future regulation, it's time to adopt the relevant law, which in turn would allow the adoption of highquality laws, eliminating their imbalances and the existence of legal conflicts, violations of systemic links between laws and by-laws, and the adoption of new laws that are not in line with already existing laws. In addition, this would enable coordination of work between the subjects of legislative initiative on a higher level to attract scientific and public potential at the stage of elaboration of the content of the draft law. Therefore, there is an urgent need to pass a law that requires the establishment of uniform requirements for normative design techniques for all subjects of legislative initiative, to specify the exhaustive list of requirements to the accompanying documents of the bill, which in turn should contain an analysis of the problem to be solved by the law and the purpose of drafting the bill, alternative variants of its solution, justification of the expediency of the chosen option, risks of the adoption of the bill. The law should specify the requirements for the examination of submitted bills, the formalization of criteria and requirements for the preparation of financial and economic substantiation of the grounds for the return of the adopted by the President of Ukraine to the Verkhovna Rada of Ukraine, and to determine the technical requirements for the form of the bill. Unjustified complexity of legislative acts manifests itself both in the complexity of texts of normative legal acts, and in the artificial complication of social relations by legal means. An illustrative example of this negative trend is the Law of Ukraine "On Securing Creditors' Claims and Registration of Encumbrances". The specified Law was developed with the aim of reducing the cost of credit resources, promoting the development of financial and commercial lending of business entities, protecting the legal rights and interests of Ukrainian and foreign investors. The need for the drafting of this Law is due to the imperfection of the existing legal framework for ensuring the requirements of creditors, investors and the creation of a single and transparent register of property encumbrances, which would provide a real and reliable picture of the financial and property status of business entities.

But it should be noted that the norms of civil law in Ukraine have always served to ensure the stability of civil relations. If a contract of lease (lease) of movable property or an agreement on the transfer of a right by a creditor to another person entered into, such contracts were subject to the enforcement provided by the norms governing the civil, civil-procedural relations and relations in the process of enforcement proceedings. The above Law does not exclude such provision, but mainly with respect to those of the encumbrances (creditors), which this Law gives priority, that is to those persons who first registered the encumbrance of the relevant movable property (the subject of 
hiring or the transferred rights). There was no need for registration, at least the kind of encumbrances that are named here. Even the very assignment of transferring the right of the creditor to another person on the basis of the transaction to the category of encumbrances did not make any sense. But it's done. The relevant requirements of the Law "On Securing Creditors' Claims and Registration of Encumbrances" are largely not fulfilled. Participants in civilian turnover consider it more acceptable to assume the risk of failure by their contractors to fulfill their obligations than to comply with the tough requirements of the said Law.

An out-of-court appeal procedure for a secured encumbrance, even if the encumbrancer has this item, also unjustifiably complicates public relations. But the legislator, having passed the named law, recognized such a complication necessary.

As regards the complexity of the text of this Law, it characterizes most of its provisions. If you repeatedly revisit the Law "On Securing Creditors' Claims and Registering Debts", it is difficult to understand who is the encumbrancer of movable property transferred by the owner to another person on the basis of a contract of hire (lease) - only the employer or also the landlord. Unnecessary complexity of the text is especially characteristic of acts of tax legislation.

The complication of tax legislation is also the departure from the traditional structure of articles of laws, which provided for the presence of parts and items in them. At the same time, the articles of the laws were small in scope, had their own titles, which ensured the convenience of using the relevant laws and gave the participants the opportunity, especially in court, to refer to the act of law to be applied. Now there has been a tendency to multiply the volume of articles of laws, including in the structure of articles of numbered parts, which are denoted in the laws as parts, then as items. In turn, these parts are divided into numbered paragraphs, sub-clauses with brackets or brackets, sub-clauses are often divided into paragraphs, which greatly complicates the legislative act.

This negative tendency (the increase of contradictions) was particularly evident in the content of the Civil Code of Ukraine in 2003 (here in after referred to as the Central Committee of Ukraine) and involves the inclusion in this law of a number of general and special provisions that were not included in the Civil Code of 1963. Thus, to Part 2 of Art. 216 of the Civil Code of Ukraine includes a general provision according to which "if in connection with the commission of an invalid contract the damage to the other party or a third party was caused by moral and non-pecuniary damage, they shall be compensated by the guilty party". To explain how this provision correlates with the special rules on the consequences of the invalidity of certain types of transactions, it is necessary to carry out a very complex analysis using methodological tools that 
nobody owns. In the presence of general rules on the legal consequences of violation of the obligation (Article 610-625 of the Civil Code of Ukraine), this Code includes numerous special rules on the consequences of violations of certain types of obligations - to conclude a basic contract on the basis of a preliminary agreement (Part 2 Article 635 The Central Committee of Ukraine), to transfer the sold goods (Article 665 of the Civil Code of Ukraine), it is appropriate to pay for work performed under a contract of employment (Article 886 of the Civil Code of Ukraine), to pay a check (Article 1106 of the Civil Code of Ukraine), etc. How are the general and special rules referred to, this should be explained by the methodology of interpreting legislative acts. But she is not there at this time. Particularly difficult to understand the ratio of Part 3 of Art. 1212 of the Civil Code of Ukraine on the consequences of the acquisition or preservation of property without a sufficient legal basis with the provisions on the return of the performed under an invalid transaction, the claim manna owner of someone else's illegal possession, the return made by one of the parties in the obligation, compensation for damage by a person who illegally acquired the property or preserved it at your own expense at the expense of another person.

\section{Status of legal and technical elaboration of legislative acts}

If, in the case of the Constitution, the negative tendencies in the development of legislation are justified by its nature as largely the result of a political compromise, then in other cases, the lack of legal and technical elaboration of legislative acts is not related to the influence of political factors on the law-making process. The factor that causes these negative tendencies in the development of domestic legislation is the lack of a desire for proper elaboration and scientific substantiation of the law-making decisions that are adopted, the lack of scientifically substantiated technology of the legislative process. It is inconvenient to say this because "very respectable" people are responsible for the improper organization of the legislative process. But it's impossible not to speak, because it is a disease suffering from a head, and therefore the whole organism (social) is ill. In essence, legislation acts are developed and processed at the level of common sense. To some extent, it is not justified by the tendency of legal science to research abstract-academic issues and even to scholastic discussions.

As Y.V. Vaskovsky wrote a hundred years ago, such comments and monographs that were created with the help of scissors and glue alone are known $^{12}$. But along with such a negative phenomenon, legal science is not deprived of signs of constructiveness, sensitivity and even depth. This reserve in the process of law-making is used very little.

\footnotetext{
${ }^{12}$ Vaskovskii E.V. Civilistic methodology. A teaching on the interpretation and application of civil laws. Moscow : JSC “CenterJurInfoR”, 2002. P. 158.
} 
Another problem of ensuring the scientific level of legislation is the necessity of developing and elaborating legislation at the highest intellectual level possible under the given conditions. This is not generally accepted. It is accepted to speak about the professionalism of people's deputies, the number of bills that they have submitted to the Verkhovna Rada, although everyone understands the level of insincerity and injustice in assessing domestic parliamentarians as lawmakers. We must speak the truth. In this way, conditions are created for the adoption of adequate situation solutions. The truth is that in the activities of the Verkhovna Rada of Ukraine the political component has received a dominant role. The intellectual component has taken its modest place and is deprived of any opportunity to prove that such a correlation of political and intellectual components in the activities of the Verkhovna Rada will not lead to good.

The above circumstances lead to the fact that products produced by lawmaking bodies should in most cases be regarded as defective. This assessment also applies to laws, and, moreover, to by-laws. If we exclude a lack of activity in the legislative body, this would have a positive impact on the law-making activity of other state bodies.

Specific insufficiently worked out provisions of legislative acts cannot be counted. Here are just some examples. First of all, let's turn to the Civil Code of Ukraine, because this legislative act is much better developed than the other. Many years of work on the draft Civil Code did not help to avoid a mistake already in its first article, where in the first part, in our opinion, the words "civil relations" were wrongly put in the middle of the text, which led to distortion of the content of the relevant legal provision (the words "civil relations" had to be put at the end of part 1 of Article 1 of the Civil Code of Ukraine). In the same part, the unsuccessful placement of words in the phrase "personal non-property and property relations" has been admitted, which gives grounds for the conclusion that there is such a phenomenon as "personal property relations". Next: in Part 1 of Art. 707 of the Civil Code of Ukraine used the word "improper" (quality) instead of the proper word (this error was corrected in the eighth year of the Civil Code of Ukraine, Part 2 of Article 900 of the Civil Code of Ukraine is written "if the contract is established", although, according to the logic of things, it was necessary write "if the contract is not established", the sentence, which is set forth in Part 5 of Article 1122 of the Civil Code of Ukraine, does not express a complete opinion, is a set of words. The lack of elaboration of bills justifies the fact that there is a process of establishing independence of the Ukrainian state, which is characterized by a rapid update of legislation, which in turn prevents the thorough elaboration of bills: on the one hand, there is an urgent social need for the modernization of legislation, on the other - there is a lack of time, experience and of funds But in the twenty-eighth 
year of Ukraine's independence, it would be time to abandon such arguments. Or society as a whole and is involved in the law-making elite realize the importance of acts of law-making as means of streamlining (rationalization) of social relations and find ways to drastically improve the law-making, or we must look for some other ways of development.

In connection with the above cannot be ignored the problem of nonprofessional interference in the lawmaking process. People's deputies cannot be deprived of the right to submit their proposals to the bills discussed in the Verkhovna Rada of Ukraine, but without professional evaluation and without professional revision such proposals should not be included in the bills.

Lack of elaboration of legislative acts entails their instability. It is good that the Verkhovna Rada eliminates its own mistakes as they are revealed. But this is not a systematic but episodic activity of the Verkhovna Rada of Ukraine. There is no systematic study of legislation and practice of its application. And changes introduced into legislative acts often require changes themselves at the time of their adoption. Let's not go into detail, but let's give an example, when the draft laws on amendments to the law experts did not read at all.

The Law "On Amendments to Certain Legislative Acts of Ukraine" dated December 15, 2005, Art. 190 The Central Committee is supplemented with the second part of the following content: "Property rights are a non-consumable thing. Property rights are recognized as real rights". The authors of the bill, which became the Law, do not understand the difference between the substantive rights that are absolute and the relative rights that are included, in particular to the content of the obligations. If they created a new theory, then, recognizing the property rights of the thing, they were morally obliged to propose changes to Art. 179 of the Central Committee, which defines the thing as "the subject of the material world" (whether the authors of the bill have ever seen such an item as, for example, the seller's property right to receive funds, which according to the contract the buyer was obliged to transfer from his account in the bank on account of the seller) and addition to the Third Book of "Ownership and other real rights" in the form of provisions on property rights not reflected in this book.

The Law "On Amendments and Recognition as Some Legislative Acts of Ukraine in Connection with the Adoption of the Civil Code of Ukraine" dated April 27, 2007 No. 997-VI amended the article. 24 of the Law "On Insurance", which is set forth in the following wording: "In case of recognition by the court of the insured citizen of incapacity, his rights and obligations under the insurance contract pass to his guardian". Still, the authors of the bill should understand the difference between legal capacity and capacity. According to the logic of things, if a person has entered into a contract of insurance of his own 
house or has entered into a contract of insurance of his life, the recognition of a person incapacitated should not lead to the replacement of the party in the obligation, but only changes the procedure for the insurer's rights and obligations: rights are exercised, and duties - are performed by the guardian on behalf of the incapacitated person. The same legislative wording provides for the replacement of a party in an insurance contract in such cases. In this way, the guardian also receives the right to an insurance payment in the event of an insured event. It does not agree with the logic of the relationship, and the shortcomings of the legislative text must be eliminated through the rule of law principle.

Paragraph 15 of Part 24 of Section 1 of the same Law No. 997-VI in the text of the Law "On Insurance" the words "insured-citizen" in all cases and numbers are replaced by the words "insured-individual" in the corresponding cases and numbers.

But in the new law, amended by the Law No. 997-VI of Art. 24 of the Law "On Insurance", the legislator uses the words "the policyholder-citizen". To date, Article 24 of the Law "On Insurance" is set forth in the following wording: "Consequences of the recognition of an insurer-physical person incapacitated. In the case of recognition by the court of the insured citizen of the incapacitated his rights and obligations under the insurance contract are transferred to his guardian and the validity of the insurance contract of civil liability is terminated from the moment of recognition of the person incapacitated. In case of recognition by a court of an insurer-physical person of limited ability, he exercises his rights and obligations of the insured under the insurance contract only with the consent of the trustee".

That is, in the title of the article, the "insured-citizen" is replaced by "the insured-individual", and the words "the policy-citizen" are left in the text, which clearly indicates the lack of elaboration by the legislator of this law. And now there is a problem, due to which it will be difficult to prove that the above formulation of Art. 24 of the Law "On Insurance" applies also to non-citizens of Ukraine, since in this Law the words "the insured-individual" are now used everywhere, and for the exclusion from this general terminology in art. 24 of the Law "On Insurance" is now used the words "insured-citizen", which does not allow the extension of this article to other individuals. Note also that private international law does not normally prevent participation in the insurance relationship between foreigners and stateless persons.

Borrowing France's experience of two hundred years ago, the legislator revealed concern about the interpretation of the content of the transaction and included the relevant regulations to Art. 213 of the Central Committee. 
The problem of interpretation of normative legal acts is much less worried by the legislature. In this regard, in the legislative acts, no general provisions are formulated, although such experience was known in the Russian Empire in the second half of the XIX century ${ }^{13}$. The more interesting are certain provisions of the legislative acts of Ukraine and international treaties concerning the interpretation of legislative acts.

Item 3 of Art. 413 of the Criminal Procedure Code, the incorrect application of the law on criminal liability recognizes, in particular, the "incorrect interpretation of the law, which contradicts its exact content". It follows that the criminal law must be interpreted precisely in accordance with its content. Another interpretation is wrong. This should not be interpreted in such a way that any logical processing of the text of a criminal or criminal procedural law is inadmissible. It appears that all logical operations with the provisions of the criminal or criminal-procedural law are permissible (except for the application of a criminal law by analogy and the application of the analogy of law).

Some guidelines are given in the Law "On Enforcement of Judgments and Practice of the European Court of Human Rights" concerning the interpretation of the Convention for the Protection of Human Rights and Fundamental Freedoms. It is attributed "for the purpose of reference to the text of the Convention" (the authors of the bill very well took into account domestic realities and understood the essence of the phenomenon: the main thing is to refer, instead of applying the Convention as part of the national legislation of Ukraine): 1) to use the translations of the texts of the court decisions and the decisions of the Commission, the established order; 2) in the absence of translation, use the original text; 3) if there is a discrepancy between the translation and the original, to be guided by the latter; 4) to use, where appropriate, the practice of the Court (Article 18 of the said Law). Part 1 of Art. 8 of the Law "On International Private Law" ascribes to the application of the right of a foreign state to establish its content "in accordance with official interpretations, practice of application and doctrine in the corresponding foreign state". This is the only provision in the legislation of Ukraine, which provides for consideration when interpreting normative legal acts of doctrine. The same problem exists with respect to national law, but it is not mentioned in any legislative act.

The Vienna Convention on the Law of Treaties, which is binding on Ukraine, devotes three articles to the interpretation of international treaties. These are the most detailed provisions on the interpretation contained in acts that have the character of acts of national legislation in Ukraine. The European Court of

\footnotetext{
${ }^{13}$ Vaskovskii E.V. Civilistic methodology. A teaching on the interpretation and application of civil laws. Moscow : JSC “CenterJurInfoR”, 2002. P. 158.
} 
Justice and Human Rights have drawn attention to the binding rules of interpretation laid down in the Vienna Convention ${ }^{14}$.

In Part 56.21 of Art. 56 of the Tax Code refers to making a decision in favor of the taxpayer in the event that the norm of the Tax Code, or when the rules of various laws or various normative legal acts imply ambiguous (plural) interpretation of the rights and obligations of taxpayers or controlling bodies, as a result of which there is a possibility make a decision in favor of both the taxpayer and the controlling body. A similar provision is included in Part 7 of Art. 4 of the Law "On the Basic Principles of State Supervision (Control) in the Sphere of Economic Activity": "In the event that the norm of a law or other legal act issued in accordance with the law implies ambiguous interpretation of the rights and obligations of the entity or body the state supervision (control), the decision is taken in favor of the economic entity". In general, such provisions, when based on the acts of the law can be adopted and one solution, and the other, the opposite of the first, should not be. But one should admit that the technical and legal elaboration of legislative acts is insufficient at this time, which justifies the inclusion in the named laws of the above-mentioned provisions.

Agreements between actors cannot be processed as carefully as laws. Therefore, it is appropriate to include in Art. 18 of the Consumer Rights Protection Law, Part 8, which ascribes "fuzzy or ambiguous provisions of contracts with consumers" to be interpreted in favor of consumers. This exhausts the attention of national legislation to the problem of interpreting legal acts and treaties (treaties).

Legal practitioners are concerned with all lawyers. But, in our opinion, the place of judges in this activity is decisive, because the lawyer's mistake, acting as a representative of the plaintiff or defendant in court, is to be corrected by the court. And it is almost impossible to fix the mistake of judges sometimes, for example, with the Supreme Court.

When assessing the work of the courts in resolving cases, it should be borne in mind that this activity consists of two main directions. In the first place, the court must provide a legal analysis of the circumstances referred to by the participants in the proceedings and the evidence that these circumstances confirm or refute. Secondly, he must give legal qualifications to the circumstances, identify and analyze the legal relationships that arose as a result of such circumstances, establish the content of the rights and obligations of the parties. In fact, the work of judges in resolving cases is an interpretation of legal acts and the adoption of conclusions regarding the content of the rights and obligations of the participants in the relevant relations.

\footnotetext{
${ }^{14}$ Salvia M. D. Precedents of the European Court of Human Rights. SPb : The Legal Center PRESS, 2004. P. 42.
} 
The courts also interpret other court decisions, treaties (in particular, treaties), lawsuits, other procedural documents, and documents confirming the material or procedural rights of participants in relevant trials. The interpretation of such acts is carried out through the prism of legislative acts, that is - also implies the interpretation of the latter.

Given all the necessary goals cannot be satisfied with the state of legal interpretation of the courts. The fact that judges, like all lawyers in general, do not have a scientifically substantiated doctrine on the interpretation of legal acts that science does not provide them with adequate support excludes the proper interpretation of legal acts in the activity of courts. Objectively due to the lack of opportunity to properly motivate judicial decisions, supplemented by subjective factors, leads to the formation of a practice of involuntary motivation of court decisions, in which, instead of proper motivation, numerous and large excerpts from legislative acts are often provided, including those that do not relate to the legal relationship that is the subject of the lawsuit. These are often abstracts, not judgments. In this way, imitation of justice is carried out.

Courts must contribute to the goals set forth above. The main means of this will be the transition to a scientifically grounded interpretation of legislative acts and the sincere motivation of court decisions. Another factor should be the awareness of the judges of the greatness of their social role. In this way, the judicial branch of government will be the center from which impulses will be given to the reorganization of society in accordance with the rule of law and higher moral values.

The European Court of Human Rights, whose practice is mandatory for domestic courts, in its judgment in V. Bendersky Ukraine stated: "[...] In accordance with the practice which reflects the principle of the proper administration of justice, judgments must adequately cover the motives on which they are based. The limits of such a duty may vary depending on the nature of the decision and must be judged in the light of the circumstances of each case [...] The law can only be considered effective if the parties' observations are actually "heard", that is, properly studied by the court". The practice of the European Court of Human Rights should be taken as a model in the practice of courts in motivating court decisions, in particular as regards the interpretation of normative legal acts.

Of course, the working conditions of judges of domestic courts are considerably worse than those of judges of the European Court of Human Rights. But we must strive for those examples of justice given by this Court. When there is a dispute between the applicant and the Government about the violation of the Convention for the Protection of Human Rights and Fundamental Freedoms, the European Court of Human Rights sets out in detail 
the applicant's position, the position of the Government, and then gives its interpretation of the relevant provision of the Convention in so far as the case is concerned. This practice has to some extent been levied by national courts, because of the mandatory precedents of the European Court of Human Rights for national courts (Article 17 of the Law "On enforcement of decisions and application of the practice of the European Court of Human Rights"). Obviously, one should expect and make appropriate changes to the procedural law provisions mentioned above. But the courts could also take the initiative and give in court decisions not long quotes from the laws, as it was today, and specifically explain why this should be understood by law.

In other government agencies, the interpretation of legislative acts is often preconditioned not by professional knowledge or skills, but by political, corporate, departmental, and even personal interests. It's easy to make sure if you carefully read the relevant documents.

\section{CONCLUSIONS}

Modern Ukrainian legislation in various sectors is characterized by a complicated structure, the presence of conflicts between separate provisions of general and special nature, incorrect use of terms of general legal significance, stylistic and linguistic shortcomings.

The above list of problems of the current legislation would be significantly reduced (at least in the legal aspect), if there was a systematically worked out and scientifically substantiated methodology for the interpretation of normative legal acts, constructed taking into account the peculiarities which are determined by the specifics of a certain relevant field of legislation.

Ukraine has every opportunity to create a highly organized society able to provide the most favorable conditions for the development of creative potential of people, the realization of this potential and the creation on this basis of new opportunities for moral, spiritual, intellectual and physical prosperity of a person. And this goal can be achieved in a short time.

\section{SUMMARY}

The article is devoted to the actual problem of the current state of Ukrainian legislation and the problem of its interpretation. The necessity and significance of the interpretation of legal acts for the legal qualification of the actual circumstances of the law-enforcement situation is researched. The tendencies of the development of legislation as an object of interpretation during the years of Ukrainian independence have been highlighted. The state of legislation is analyzed through the prism of organization of society in the state. 
In addition, the author analyzed the cases of unjustified complication of legislative acts and revealed an increase in contradictions between their provisions. The state of legal and technical elaboration of legal acts is determined and the process of incorporating new laws into the system of legislation is examined. The legislative influence on legal interpretation activities, as well as the place and level of interpretation of legal acts in lawenforcement activity are investigated.

\section{REFERENCES}

1. Alekseev S.S. Ascension to Law: Searches and Solutions. Moscow, 2001. $752 \mathrm{p}$.

2. Bocharov D.O. Law-enforcement activities: concepts, functions and forms: Problem lectures. Dnipropetrovsk : AMSU, 2006. 73 p.

3. Vaskovsky E. V. Tutorial of the Civil Process / ed. V.A. Tomsinov. Moscow : Publishing house "Zertsalo", 2003. 464 p.

4. Vaskovskii E.V. Civilistic methodology. A teaching on the interpretation and application of civil laws. Moscow : JSC "CenterJurInfoR", 2002. 508 p.

5. Vitushko V. New technologies for the interpretation of law. Justice of Belarus. 2001. № 1. URL: http://www.justbel.info/ search.htm.

6. David R., Joffre-Spinoza K. Basic legal systems of the present. Moscow : International relations, $1998.400 \mathrm{p}$.

7. Dodin E.V. Evidence and Evidence in the Law Enforcement of the Soviet Government Bodies. Kiev; Odessa, 1976. 127 p.

8. Kozlov A.S. On the Conceptuality of the Theory of Evidence in the Jurisdiction. Actual problems of the theory of legal evidence : sat. scientific book. Irkutsk, 1984. P. 4.

9. Kuhn T. The Structure of Scientific Revolutions. Moscow, 2002. 608 p.

10. Rabinovich P.M. Fundamentals of the general theory of law and state: teach. Manual. View. 5th from changes. Kiev, 2001. 176 p.

11. Salvia M.D. Precedents of the European Court of Human Rights. Saint Petersburg: The Legal Center PRESS, 2004. 1072 p.

\section{Information about author:} Samsin I. L.,

Doctor of Law, Associate Professor, Professor of the Department of Constitutional, Administrative and Financial Law of the Khmelnytsky University of Management and Law 8, Heroyiv maydanu str., Khmelnitsky, Ukraine 